PART ONE

The Geography of Civilization 



\section{Seeing Like the Nation}

In 1936, Nakanishi Inosuke articulated his frustration with what were called "observational travelers" and their not very observant travelogues: "The experts who write the authoritative accounts know geography, human feelings, and customs well of course. But they are writing nothing more than guidebooks. They do not have 'eyes.' Because of this, they do not have a worldview. And because of this, they are not painting a picture of today."

Nakanishi was a prolific proletarian writer. He had worked in Korea in the 1910 s as a journalist. Upon his return to Japan in 1919, Nakanishi turned to writing novels. His books never won awards, but they remain some of the most interesting Japanese-language works to wrestle with the dislocation and dispossession that attended Japanese colonialism and imperialism. His 1936 Shina Manshū Chōsen (China Manchuria Korea) and 1937 Taiwan kenbunki (A record of things seen and heard in Taiwan) are two of only a handful of travel accounts published during the imperial period that were overtly critical of imperialism. ${ }^{2}$

For Nakanishi, to have "eyes" meant to be able to see the structural effects of colonial rule, to see objects and peoples not as representatives of static "places" but as manifestations of social relations. In an essay entitled, "Okoreru Korea" (Angry Korea), Nakanishi described in poignant detail what he meant: "Describing a group of Koreans as a wave of white robes has become a dream of the past. They [now] wear the khaki and gray clothes of dirty laborers." ${ }^{\prime 3}$ The sights that seemed to represent "Korea" only obfuscated the reality of an imperial economy built on low-wage colonial labor. To write without eyes meant not only to write without a worldview but also to perpetuate "outrageous" distortions that fueled imperialism and masked what Nakanishi saw as the true state of a world defined by class exploitation. 
Nakanishi was right to critique travelers' accounts of the colonies for their lack of a critical perspective on social relations within the empire. But Nakanishi was not quite right to say that they lacked a worldview. Japanese imperial travelers and colonial boosters had eyes-just not for the unequal social relations that Nakanishi sought to expose. To borrow James C. Scott's phrase "seeing like a state," imperial travelers "saw like the nation." ${ }^{4}$ Modern states make terrain legible and manageable through procedures such as cadastral surveys and urban planning. Similarly, imperial travelers and colonial boosters sought to construct a place for the nation by observing colonized lands through the eyes of a kokumin, or national subject.

In the first decades of imperial tourism, to see with nationalist eyes meant to unsee the obvious differences between the experience of the individual and the experience of the nation as a whole, and instead, to see in the collective past and future tense. Gotō Shinpei, who was as much a pillar of Japanese colonialism as Nakanishi was a critic of it, described perfectly what this meant in an article on tourism to Taiwan. "If one does not recognize that it was the blood and souls of many pioneers commended to the mud of this land and the frantic toil and management of our predecessors that has at last called forth the sugar of today," he wrote, "one's observation stops at that of the simple naked eye-the eye of the mind stays shut." To see meant to look, to refine one's gaze and filter it through one's imagination: "If we turn our eyes to the future, it is possible to see how Taiwan will gradually abound in splendor-complete proficiency as a land of industrialized agriculture, the complete development and extraction of that which is now hoarded in the land-and if we don't see this future then we are not fulfilling the job of seeing Taiwan."

Imperial travelers filtered their observations of the empire through a nationalist lens. They saw the present in terms of a national future and a national past. They abstracted from their own limited experience an observation about the nature of a place that they imagined would hold true for all national subjects who viewed the same territory - if they chose, unlike Nakanishi, to view it that way. Upon their return, imperial travelers presented their perspectives as the authoritative ones through a combination of their elite social position and the value attached to "firsthand observation" of the colonies.

We start with the question of imperial travelers' eyes because in order to understand why the territorialization of national identity on colonized lands revolved so closely around imperial tourism, we must first understand the relationship between the practice of observation that imperial tourism encouraged and the social position of the travelers who were chosen to undertake it. Like Mary Louise Pratt's eighteenth- and nineteenth-century European travelers, Japanese imperial travelers sought to make imperial expansion "meaningful and desirable, even though the material benefits accrued mainly to the few." ${ }^{\text {If }}$ early modern European travelers described Africa, the Americas, and Asia in terms of a "planetary consciousness" 
and framed their observations as the discovery of natural laws and natural social orders that would be beneficial to all of humankind, early twentieth-century Japanese imperial travelers framed their observations in terms of an intertwined planetary and national consciousness. On the one hand, they sought to describe particular observations in terms of their broader historical meaning, to define the key sites of Japanese imperialism and colonialism as episodes in a larger story of human progress. ${ }^{7}$ On the other hand, they also denied how class shaped their experiences and that of others by representing their observations as those of a universal Japanese national subject, a traveling everyman.

The method and results of their observations tell us much about the practices and politics of firsthand observation that would make imperial tourism such an appealing vehicle for spatial politics and imperial travelers such willing participants in the process. We focus here on imperial tourism to Korea and Manchuria because it was in the context of fostering affective connections between national subjects and these "new territories of the state" that imperial tourism first emerged, in the years immediately following the Russo-Japanese War in 1905. Imperial travelers' observed Korea as a place firmly on its way to becoming Japanese. These observations differed markedly, as Helen J. S. Lee has argued, from those published by largely lower-class Japanese settlers, who portrayed Korea as a place "awash with tension, struggle, and competition" between Koreans and Japanese. ${ }^{8}$ Imperial travelers' accounts of Manchuria-in particular, their observations of the site of 203-Meter Hill, the site of the Russo-Japanese War's most famous battle-likewise represented Manchuria as a site of national triumph, in contrast to soldiers' far more circumspect recollections of the battle, which questioned the value of the sacrifices that the largely conscript army had been asked to make in the name of territorial acquisition. Indeed, it was precisely in this erasure of conflict and competition from the present and its displacement onto the past that the worldview of imperial travelers emerged.

\section{A CRISIS OF EMPIRE}

The problem was this: Japanese subjects did not seem to care about empire. They did not care enough, anyway. And when they did, they sometimes cared in the wrong way (for example, when "caring about empire" meant suggesting the illegitimacy of territorial conquest). Hindsight, they say, is twenty-twenty. But in this case, the clarity with which history has explained Japanese imperialism-as the logical complement to mass nationalism in an era of geopolitics and as the logical outgrowth of industrialization in the metropole-obscures the extent to which many Japanese imperialists saw imperialism as a project constantly in crisis. ${ }^{9}$

Perhaps crisis is too strong a word. Yet if we are to use our "eyes," in Nakanishi's terms, to read the history of imperial tourism and its spatial politics, we must be 
prepared to suspend our received notions about the symmetry of state and nation. Instead, we must put one foot into the shoes of those colonial boosters who saw imperial tourism as essential to the production and maintenance of emotional bonds between the nation and its imperial territory and the other foot into the shoes of imperial travelers, who went forth to recast colonized territory as "the national land" (kokudo).

Our story starts, at least provisionally, in 1905. In this year, Japan claimed victory in the war against Russia, a war that had been fought primarily in Manchuria and Korea. The Japanese victory came at the cost of some eighty thousand (largely conscripted) Japanese lives. The end of the war was for that reason, if none other, widely celebrated. But the central government and the media had also worked hard to foment mass nationalism during the war, and in this sense the victory was celebrated not only as an end to the killing but also as Japan's triumph on the world stage. Though the promotion of mass nationalism had begun in earnest with the 1894-95 Sino-Japanese War, it was helped immensely a decade later by the large number of conscripted troops fighting in Manchuria and Korea-nearly ten times the number that had fought in the Sino-Japanese War-and by the introduction of new technologies for bringing the battlefield to the home front. Newspapers ran photographs of battlefields and competed for the most up-to-date reports, which they received via telegraph. The live narration of silent newsreels of battles brought audiences in Tokyo and Osaka to a fever pitch of jingoism, while new infrastructure, such as Hibiya Park in Tokyo, encouraged mass sentiment as never before. ${ }^{10}$ It was this reservoir of patriotic sentiment upon which the Tokyo Asahi shinbun (Tokyo Asahi Newspaper) drew when it invited applications for the first travel expedition to Japan's newest territories a year later: "Go! I will go too-to the new paradise that our Japan has opened up after two years of great hardship." ${ }^{11}$

But all was not as celebratory as the advertisement suggested. Jingoistic press statements about the expedition contained elements of performance and coercion. The Treaty of Portsmouth, which settled the conflict, transferred to Japan the Russian leasehold and railway concession in southern Manchuria and placed Korea under the guidance of Japan as a "protectorate." While Korea and southern Manchuria were under Japanese management, however, they were not placed under Japanese sovereignty. Nor was Japan granted an indemnity from Russia to cover the extraordinary costs of the war, a practice that had been a standard component of previous conflicts between Western and Asian states and had, in fact, even been part of the resolution of the previous Sino-Japanese War. At the news of the settlement's paltry terms, some thirty thousand people in Tokyo gathered in Hibiya Park to demand that the emperor reject the treaty. In other words, they rallied in opposition to, rather than in support of, the government. ${ }^{12}$ Protestors overturned streetcars and set fire to police boxes. Clashes with police resulted in nearly one thousand casualties. 
The technologies and practices that made the Russo-Japanese War such a powerful vehicle for fomenting mass nationalism also made possible powerful and widely disseminated critiques of the war. In some areas within Japan, the construction of memorials to what the government and local elites termed the "honorable war deaths" and "voluntary sacrifices" of Japanese soldiers began even before the war had ended. But so had criticisms of the war. The increased taxes to support the war effort fell heavily on the urban lower classes, especially rickshaw pullers and craftsmen, who joined in demonstrations to protest the cost of the war. People in the villages of those conscripted made pilgrimages to shrines to pray for the safety of their hometown kids-not, as Naoko Shimazu points out, a necessarily jingoistic act. ${ }^{13}$ Poets even inaugurated a new theme for the era-"war-weary poetry"-that lamented the human costs of the conflict. Emblematic of this group was Yosano Akiko, whose poem to her conscripted younger brother, "You must not die" (Kimi shinitamaukoto nakare), earned her the opprobrium of the pro-war literary establishment, one of whom called the poem "unforgiveable as a Japanese national (kokumin)." ${ }^{14}$

You now indeed, succeeding a loved father,

Are master of that house which in Sakai

For countless years has kept the merchants' code.

O no, my brother; no, you must not die.

Let the damn fortress at Port Arthur fall

Or let it stand, what difference can it make

To merchant folk who are not called to cramp

Their lives in patterns cut for samurai? ${ }^{15}$

The wartime debate over the legitimacy of the war coalesced around the question of who the kokumin, "national people," were and what their best interests would be. ${ }^{16}$ Yosano's critique was one of many. But it spread widely because, in the words of Sho Konishi, it "poetically rendered" a central concern of antiwar activists-that the fight to claim territory in Manchuria was not, as the government would have it, in the interests of the nation but rather in the interests of the few. ${ }^{17}$ Were the kokumin a horizontal community of compatriots that existed prior to the state? Or, as in Yosano's formulation, was the idea of a kokumin merely an ideological tool that reframed the interests of the few as the needs of the many? Fueling the debate was the fact that kokumin itself was an extralegal category, a type of political identification that emerged in thought and action rather than in ethnicity or nationality. ${ }^{18}$ It was not the same category as that which was used to define legal Japanese citizenship-the category of Japanese, Nihonjin, was defined by the 1899 Nationality Act as those born to a Japanese father. Nor was it the category used to describe all of the people within the territory of the state, who were instead defined 
by the Constitution as the emperor's subjects, shinmin. Moreover, the term was not linked to any static geography of inside and outside or new and old territory but instead moved in little relation to, as we shall see in chapters 3 and 4, the hardening of a geographic structure of imperial citizenship. It was likewise unrelated to the franchise. The right to vote was extended to Hokkaidō residents (who met tax qualifications) in 1904, and residents of Okinawa got the right to vote in 1912, while in 1925 the Universal Suffrage Act excluded both Japanese and colonized residents of Korea, Manchuria, and Taiwan from voting for parliamentary representation. ${ }^{19}$ Yet, particularly after the 1930s, even colonized subjects were expected to perform kokumin-ness through the use of the Japanese language and eventually, for men, through military service in order to demonstrate their suitability for the rights and responsibilities of citizenship.

Instead of a strict legal category, then, kokumin was an affective and performative one. Commentators used it to further their own political positions on how Japanese nationals ought to behave and how the government ought to behave toward them. When the term first emerged, it was as a liberal rallying cry during the 1870 os Freedom and Popular Rights Movement, in opposition to what these activists saw as the statist centralism of the ruling elite. Other activists used kokuminshugi, "national people-ism," to connote a political formation based around the protection of liberal individualism. ${ }^{20}$ But the powerful also used kokumin to coerce particular behaviors out of the less powerful-to encourage subjects to behave as kokumin. In the lead-up to the promulgation of the 1889 Constitution, the state quickly co-opted the term to denote "patriotic citizens," especially those who promoted what Carol Gluck has called the "civil morality" of the state. ${ }^{21}$ During the Russo-Japanese War, the government continued to use the kokumin ideal to exhort the Japanese people to support the war effort and, more broadly, to encourage loyalty to a government that was, through tax qualifications on voting and the separation of administration from parliamentary representation, largely insulated from the public.

The war also brought to the fore tensions in the modern nation-state ideal itself. As Sho Konishi argues, the antiwar movement forwarded a powerful critique of modern international-relations theory and its vision of a peaceful world founded on a global order of territorial nation-states. As articulated by figures as wide ranging as Theodore Roosevelt, who presided over the settlement of the Russo-Japanese War, and Nitobe Inazō, the founder of colonial policy studies in Japan, conflict was not an inherent component of the Western concept of civilization but rather external to it, the fault of barbarous societies stuck in a "state of nature." In this framework, the expansion of civilization and its spatial framework of territorialized nation-states was a necessary and morally defensible goal of civilized nations. For Yosano and her fellow antiwar activists in the leftist press, however, the idea that the placement of all the world's territory under the sovereignty 
of individual nation-states would lead to world peace "was not just a jargon of diplomacy to mask the intent of territorial gain."22 It was a delusional, "utopian" logic that countenanced colonialism and wars of imperialist expansion, such as the Russian and Japanese battle over the control of Manchuria and Korea, in the name of a future of peace and order. ${ }^{23}$

In the context of the scramble for territory and spheres of influence in early twentieth-century East Asia, generating affective ties to these new territories of the state and, through this process, producing "good" national subjects became a serious concern of both the central government and colonial boosters in Manchuria and Korea. Fearing that the Japanese public would quickly lose interest or even turn against Japan's expansion abroad, at war's end, the government embarked on new programs of indoctrination to reclaim the narrative of the Russo-Japanese War as a victory for the nation. The emperor appeared at celebration rallies and issued rescripts proclaiming his support for the peace treaty. The Ministry of Education renewed its commitment to teaching ethics in schools-classes that encouraged students to see their primary responsibility as service to the state. ${ }^{24}$ And in July 1906, two ships departed Japan for Manchuria and Korea, territories that had been the site of the most recent battles and were now-with the peace settlement-within the internationally recognized sphere of interest of the Japanese state. One was the Tokyo Asahi Newspaper's four-hundred-participant "Manchuria-Korea Travel Ship" (Man-Kan jun'yū sen). ${ }^{25}$ The other was a ship carrying nearly six hundred students and teachers sponsored by the Ministry of Education and the army. ${ }^{26}$

\section{THE BIRTH OF OBSERVATIONAL TRAVEL}

The departure of the two travel expeditions for Manchuria and Korea marked not only the "birth of overseas travel," but also the birth of "observational travel" (shisatsu ryokō) as a core component of the government's larger project of producing good national subjects. ${ }^{27}$ Given its nationalistic overtones, this practice has understandably been called "self-administered citizenship training." ${ }^{28}$ But the production of nation-states and national subjects did not take place in a vacuum, with the territorial domain and national consciousness of each individual nation-state expanding outward into a white space of unclaimed territory. It was embedded in the presumptions of the modern inter-state system, within which Japanese leaders imagined Japan as one of many centers around the globe from which civilization would emanate, and in the system's utopian logic, which countenanced territorial expansion as a necessary evil for the larger good. In other words, observational travel was not only a way of teaching national subjects to understand Japanese citizenship in the context of a national land that incorporated conquered territory. It also positioned that territory within a future global order of territorial nation-states. The firsthand observations of travelers took place within this dual 
order of the geography of civilization. Thus observational travel might more profitably be considered a practice rooted not in the pathology of a particularly Japanese nationalism but as a new stage in the larger-and longer-project of naturalizing the imperialism of civilization around the globe. ${ }^{29}$

Travel itself was not new to Japan. Domestic travel had been a popular leisure activity in Japan since at least the late eighteenth century, when pilgrimage and "medicinal hot springs travel" were the only recognized reasons for a commoner to leave home. Presenting a famous shrine or a hot spring as their official destination, commoners would tour a wide area to and from that spot, visiting local sights along the way. ${ }^{30}$ Moreover, the Meiji government had already been sending elite students and officials on sponsored study travel to the United States and Europe for nearly fifty years. ${ }^{31}$ In the 188 os, higher schools adopted this practice by sending students out on educational trips to local areas so that they might practice disciplined observation outside of the classroom. And since 1893, an unofficial organization of political and commercial elites, the Welcome Society (Kihinkai), had facilitated the travel of elite foreigners to Japan. ${ }^{32}$

But observational travel to the new territories differed from these previous practices in two senses: one, the purpose of travel was neither leisure nor the experience of particular sites but rather the observation of the national land and its component parts; and two, it was heavily managed by the central and colonial governments and by colonial enterprises to achieve a particular political end-the production and reproduction of Japanese national subjects who had emotional bonds to colonized land. It was not the act of travel, in other words, that produced the good national subject, but rather the act of observing-or, more precisely, the way in which imperial travelers translated their experiences into "observations." ${ }_{33}$

To observe the national land meant to see the landscape within the dual order of the geography of civilization-in terms of the history of the Japanese nation and, at the same time, in terms of a future global order of interlinked and commensurable nation-states. The next chapter addresses the latter half of this equation. Here, we direct ourselves to the first problem-what it meant to see the land in terms of the history of the Japanese nation. It is here that travelers began the work of constructing observations of the national land that collapsed the gap between their personal experiences or relations to historical events and the official history of these events. Kanō Shigorō, the principal of Tokyo Higher Normal School, laid out the rules as he dispatched his students to Manchuria and Korea in 1906: "A great many kokumin know only part of the layout of the battlefields and the conditions of warfare from a few newspapers or magazines, and chances to witness the sites of victory are scarce," he wrote. "Because of this, they are not able to form deep impressions of the war." ${ }^{34}$ Kanō encouraged his charges to go beyond this. "Those who will become teachers must not stop at simply reading accounts of battles or gaining information about the war from conversations with others," 
he exhorted. Rather, "they must go themselves to the battle sites, reflect deeply [on them], and use these materials to enlighten today's subjects and guide the next generation." 35

The idea that firsthand observation of objects or phenomena in isolation produced knowledge is, of course, a (if not the) foundational principle of scientific thought. Training in scientific observation was a core component of the educational curriculum in Japan, as elsewhere. But observation was also a "transposition of the real" into received categories of experience and explanation, and it was in this vein that the first imperial tours were envisioned. ${ }^{36}$ Such a practice was already at the core of new methods of education in Japanese primary schools, where educators used Swiss pedagogue Johann Heinrich Pestalozzi's “developmental learning" method to improve students' individual faculties through direct experience and sensory-based observation. ${ }^{37}$ One of the goals of the Meiji state's educational system was the reorienting of local life around the abstract categories of modern society-developmental time, civility, and the nation. In this context, the boundary between the categories of "knowledge" and "experience" necessarily blurred. Experience came to be determined not by "what is around the individual, but how that environment connects with abstract criteria-knowledge, be it objectified by science or a national common sense." ${ }^{38}$

Geography education was particularly suited to active learning. Meiji-era elementary school teachers often took their students on field trips in order to transform the local landscape into a laboratory of geographic observation. The purpose of these trips, which visited local monuments, historic sites, and topographical landmarks, was to "increase the child's powers of observation" by fostering "the students' capacity to observe what is in front of their eyes." 39 But what students actually learned to observe was the metageographic relationship between their locality, their region, and the nation-state, in which "local materials" such as historic monuments and shrines linked the students' home communities to the nation as a whole..$^{40}$ For Meiji-era elementary school students, for example, part of seeing Nagano Prefecture's Mt. Ontake was seeing it as "the second highest mountain in Japan after Mt. Fuji." ${ }^{41}$ For older students, the destinations were farther afield, but the process of observation was the same. One 1902 all-Japan guide for school travel built upon the local-regional-national metageography by organizing the sites to be seen by prefecture, starting with the publisher's locality of Osaka and combining to make up all the sites to be seen in Great Japan (dai Nihon). ${ }^{42}$

The "blurring of the difference between knowledge and the sensate in the logic of the nation" is readily apparent in the accounts of the first imperial travelers to Manchuria. Imperial travelers attempted to describe the knowledge that they gained through travel in the terms of a nationalist metageography of exclusive and stacking territorial relations. ${ }^{43}$ Relaying his impressions of his journey to Manchuria and Korea, for example, Miyatsu Kenjirō of Kōbe, a member of the 1906 Tokyo 
Asahi Newspaper expedition, chastised his fellow countrymen for their failure to nest Russian Dairen within the space of Russia itself. He had heard from many people who were impressed by the achievements of the Russians in Dairen and who worried about whether Japan had the resources to rebuild the infrastructure that the Russians had first installed, let alone develop Dairen further. But to truly observe the current situation in Manchuria, Miyatsu argued, one had to understand how to organize the land under observation into the larger territorial categories of the modern world. In this sense, those who made one part of Russia stand in for the whole of the country had it precisely backward. This was an "error in observation." Instead, one should see Russian Dairen in the context of Russia as a whole, where, he noted, there were many internal disturbances that were weakening the country. Dairen did not describe Russia; rather, Russia described Dairen. Applying his style of "correct" observation to the now Japanese city in front of him, Miyatsu argued that the spirit of the nation would ultimately determine the fate of Japanese Dairen. "Even if it is a major power, Russia lost the war. . . . If Japan goes forward by uniting agriculture, commerce, and industry with the Yamato spirit, Japan will advance to a promising future," he concluded. ${ }^{4}$

The line between correct and incorrect observations-and the line between where one nation's spirit took over as the agent of history from other nations occupying a given land-was not so easy for every traveler to determine. In the context of imperial nationalism, the nationalist metageography that worked so neatly in the provinces of Japan's main islands existed in uneasy tension with the core-periphery metageography of the expanding empire. ${ }^{45}$ Fellow traveler Kitamura Kikujirō of Osaka stumbled over the indeterminate boundaries and political geography in his observation of the region. "Even though I had a bit of knowledge about Manchuria and Korea through reading books and hearing lectures, it wasn't until I actually set foot there that I thought, Oh, I see, and understood," he wrote. Acquiescing to the problem of perspective- "ten people will have ten different impressions, depending on their own positions"- he nevertheless felt confident that Manchuria and Korea were now in some sense part of the territory of the Japanese state and perhaps part of the space of the Japanese nation. "Our Japan is a victorious country and an advanced country," he concluded, "and now I feel deeply that as individuals and as a group we have a heavy responsibility toward the national people (kokumin) of Manchuria and Korea." ${ }^{6} 6$ The already vague meaning of kokumin makes this statement particularly hard to parse. It is not clear if Kitamura intended to indicate that the people of Manchuria and Korea were distinct national peoples. Manchuria remained sovereign Chinese territory, even if parts of its territory were under Japanese administration. If Kitamura was indeed referring to the people of Manchuria and Korea as distinct national peoples, one expected that he would speak of the national people of Korea and China. Moreover, Kitamura envisioned some relationship between Japan or the Japanese kokumin 
and the national peoples of Korea and Manchuria, but he likewise left the precise nature of that relationship undefined. Kitamura's confusion should not be taken as a sign of his own failure of observation but rather of the confused reality of the burgeoning system of territorial nation-states, as opposed to their theoretical ideal. It also reflected the more intentional obfuscation of the national status of Manchurian residents that Japanese imperialists undertook in order to undercut Qing objections to the expansion of Japanese control over the region. ${ }^{47}$

If observing these lands meant first constituting them within a nationalist metageography, placing them within the history of the Japanese nation also required the exertion of the self as an active agent who held affective ties to what Timothy Mitchell has called the "world of representations." ${ }^{8}$ In this sense, the idea of national land emerged as a vehicle for bridging the gap between the idea of Manchuria and Korea as new territories of the state-an idea that some, like Kitamura, struggled to populate-and the space of the nation. If observing the new territories meant deploying territorial containers that were themselves subjective and historical frameworks for parsing the world, it also demanded the deployment of the travelers' subjective selves far more directly in terms of its requirement that travelers bear witness to the national land. In this sense, national land was a resource for the nation and its spatial reproduction not only in terms of the use and exchange value of its commodities but also as a site through which travelers could produce a sense of themselves as having an authentic claim to a particular piece of land.

Part of the value of observation for travelers was the ability to claim what Dean MacCannell has termed the "authentic" knowledge of the tourist-the kind of knowledge that comes from the tourist feeling like he or she understands "the truth" of the site in a way that is not available to those who have not seen it firsthand. ${ }^{49}$ Indeed, even as travelers claimed a universal perspective, the authenticity of the tourist's knowledge demanded, in some sense, the acknowledgement of a subjective position, of a body that had traveled to see the land firsthand. This was, as Nicholas Entrikin has put it, the "betweenness" of place-the existence of a here and a there was a matter of both objective certainty and subjective perspective..$^{\circ}$ Observation of the national land thus transposed the real in yet another register, by engaging travelers in emotional reenactments of a Japanese national history as if their experience of a particular site could represent the experience of the nation writ large. ${ }^{51}$ The emotional component was particularly important in the aftermath of the war, when commentators worried that nationalist sentiment was fading even among the more well-to-do. In another of the unintended consequences of mass nationalism, the postwar generation took the Meiji state's mantras of "rich country, strong army" and "to rise in the world" (risshin shusse) and transformed them into calls for individual success and individual wealth over state loyalty. Tokutomi Sohō, editor of the pro-government newspaper Kokumin shinbun (Citizens' news), 
complained that the younger generation had lost "all, or at least a major portion of, the national awareness" that had characterized the previous generation. ${ }^{52}$

Indeed, unlike other mnemonic sites relating to the extra-archipelagic history of the Japanese nation-sites that included a growing number of memorial and commemorative monuments to the Russo-Japanese War in Japan, visits to the Toyokuni shrines of Toyotomi Hideyoshi (the architect of two late sixteenth-century invasions of Korea), and exhibits at expositions-the first tours of Manchuria and Korea brought travelers to the sites of historical events to anchor the oftentimes fuzzy space of national history in actual (contested) territory. A visit to Genbu Gate in Heijō (K. P’yŏngyang), for example, allowed one student on the 1915 Hiroshima Higher Normal School trip to "look back on that time twenty years before, when our empire first appeared from behind the curtain on the world stage" - a reference to the 1894-95 Sino-Japanese War, which was fought largely in Korea..$^{53}$ The preservation of sites assisted in this reenactment. "Heijōs old battlefields are things from twenty two years ago," he wrote, "but [markers along] the pathway explain the preserved battle sites so that you are somehow able to put yourself back in that time." 54 The school's other diarist noted that "the land we walk on now contains innumerable historical marks made by our countrymen (kokumin) hundreds of years ago." ${ }^{5}$ Pusan (K. Busan) likewise sparked the second diarist to imagine himself in a relationship with the soldiers in Katō Kiyomasa and Konishi Yukinaga's sixteenth-century armies. Pusan was the site where Hideyoshi's invasion force landed; the student wrote, "[It is a place] where the blood of countless of my countrymen runs." ${ }^{56}$

But it was the battlefield sites of the Russo-Japanese War that received the most emphasis in these early years. This was for two reasons. First, the Treaty of Portsmouth did not settle the conflict between Japan and China over the control of Manchuria; it simply shifted the terms of debate from whether Japan would have a stake in the territory to how much of a stake it could claim. Second, as we explore in the next chapter, the growing number of Japanese residents of the Kwantung Leased Territory, generally white-collar workers attached to the South Manchuria Railway Company and its growing kingdom of industries, felt their place within the nation to be unsteadily acknowledged by their metropolitan counterparts. For both issues, however, the response was the same-to bring imperial travelers to the battlefields of the Russo-Japanese War so that they might develop affective ties to the contested territory. Standing under a hole in the roof of the Memorial Exhibition Hall at Port Arthur (J. Ryojun; C. Lushun) and hearing the story of how it got there, for example, prompted students to contemplate the sacrifice of Russian and Japanese soldiers. One Hiroshima Higher Normal School student noted that the hall had been the Russian general headquarters during the war. But, "our army" (waga gun) launched a shell that went right through the roof, which "made the meaning of the memorial all the more deep." ${ }^{57}$ 


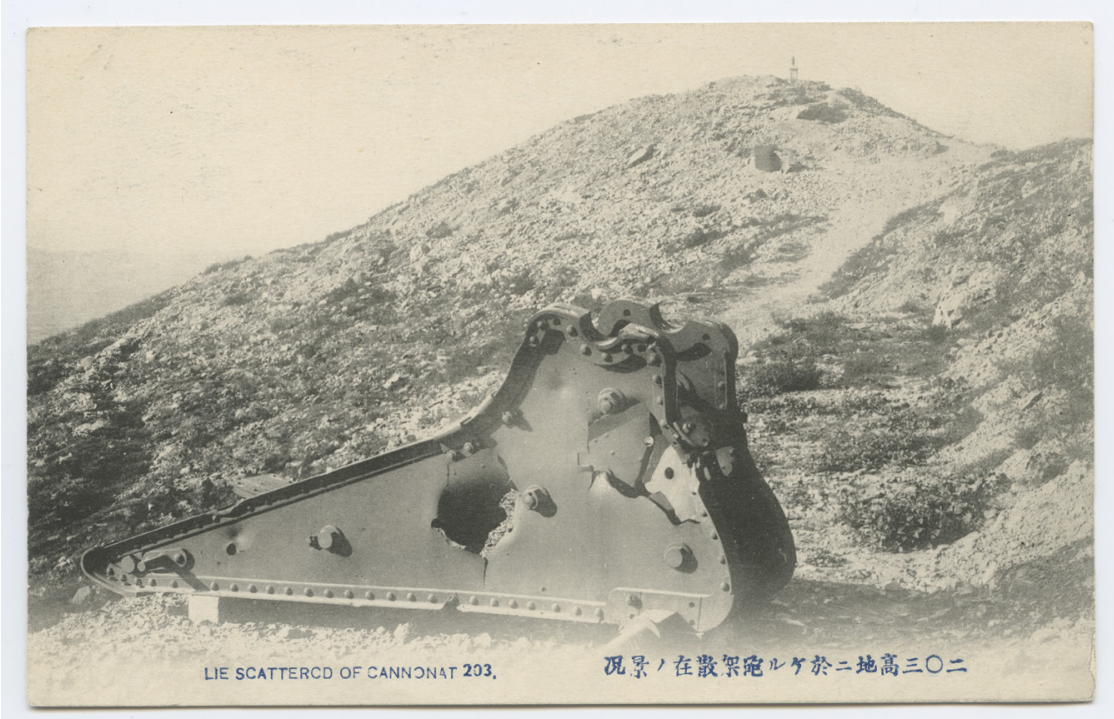

FIGURE 2. The remains of a cannon at 203-Meter Hill. Postcard, c. 1910s. The ruins of battle were left on the hill like props on a stage. Digital image courtesy of East Asia Image Collection, Lafayette College Libraries, Easton, PA. Image ipo162.

At 203-Meter Hill, the government of the Kwantung Leased Territory provided tour guides, often former soldiers, to narrate the events of the battle. The battle of 203-Meter Hill had been the bloodiest of the entire war. For months, wave after wave of Japanese soldiers climbed up a barren hill toward dug-in Russian machine-gun positions at the top. Thousands were killed. The eventual capture of the hill led directly to the artillery bombing of Russian ships in the harbor of Port Arthur, which could be sighted from the top of the hill, and thus the battle was quickly commemorated as the highpoint of the war and of the patriotic sacrifice of the soldiers who fought in it. Tour guides' narratives were laden with emotional content, and in later years, guides would compete to be known for the particular way in which they retold the story of the final battle..$^{58}$ But the landscape itself also played a role, as tour guides linked the narration of the battle with the experience of walking up the hill.

Student travelers described how they vicariously experienced what the soldiers had felt. The report from one student in the Tokyo Higher Normal School's English Club illustrates how the students made use of the emotional narrative and the physical terrain to imagine themselves in the shoes of the soldiers. The students gathered at the top of the hill, listening to an officer recount the story of the battle. 
According to the officer, the last assault began at five in the morning, as planned. Taking advantage of the fast gathering darkness, our soldiers pressed on [toward] the rampart, but the sword-like hills, the irresistible machine-guns, the scattered bodies of the killed and the wounded were serious impediments to their progress. Now marching, now stopping, they came always closer to the rampart. Just then, strains of our national anthem arose from the left wing of our army. All cleared and encouraged, they overthrew the enemy, who now appeared to give way somewhat, and sprang over the rampart in high spirit. A hand-to-hand fight ensued, and at daybreak our regimental flags of the Rising Sun arose high above the heap of the enemy's dead. ${ }^{59}$

The student quickly transposed the guide's narration into his own observation, neatly using his own firsthand experience of the hill to claim an authoritative memory of the event. "Well, our schoolmates," he wrote, "I can imagine how the brave soldiers this time forgot the strain and exertion of the furious attack in the joy of victory and in shouting the deafening 'Banzai!'” Indeed, for this student, reenacting the event on the site itself animated the land with the emotional force of patriotism. "Greatly moved by the officer's lectures and standing still on the traces of this memorable fortress," he concluded, "I was quite oblivious of all else and absorbed in deep meditation."60

Standing at the memorial that was later erected atop 203-Meter Hill, Hiroshima's second diarist also had a visceral experience of the terrible battle. He transcribed the words of the group's guide as he described how the Japanese battalion attacking the hill went from eighty soldiers to only tens in the first day. Yet that night, they made earthen defenses, and by the next day, after climbing over the bodies of those who had died before, they planted the Japanese flag on top of the hill. The diarist then jumped in to narrate the story relative to his own perspective: "They stood atop that hill. That place is right next to today's memorial tower and viewing platform." ${ }^{61}$ Indeed, the hill itself did much of the work for the tour guides in emphasizing the patriotic sacrifice of the soldiers. As one student from Keijo Public Middle School later wrote, "If it is this hard to climb the hill on this nice road, it must have been a nightmare to climb it during battle." ${ }^{2}$

The reenactment of a Japanese national history in situ encouraged particular forgettings and unseeings that were essential to the maintenance of the fiction of a kokumin defined by a shared historical experience. Battlefields were preserved, as the Society for the Preservation of Manchuria's Battlefield Ruins (Manshū senseki hozon kyōkai) explained in 1914, to "make public our everlasting loyalty to the national land" (kokudo) and to remind the world of the "national strength" of Japan. ${ }^{63}$ And to a certain extent, the transformation of Port Arthur into a "town of historic battlefields" (senseki no machi) evidenced the concern of Japanese officials and residents in the Kwantung Leased Territory and the Railway Zone over the tenuousness of Japan's claim to the territory. But if the ambiguity of Japan's 


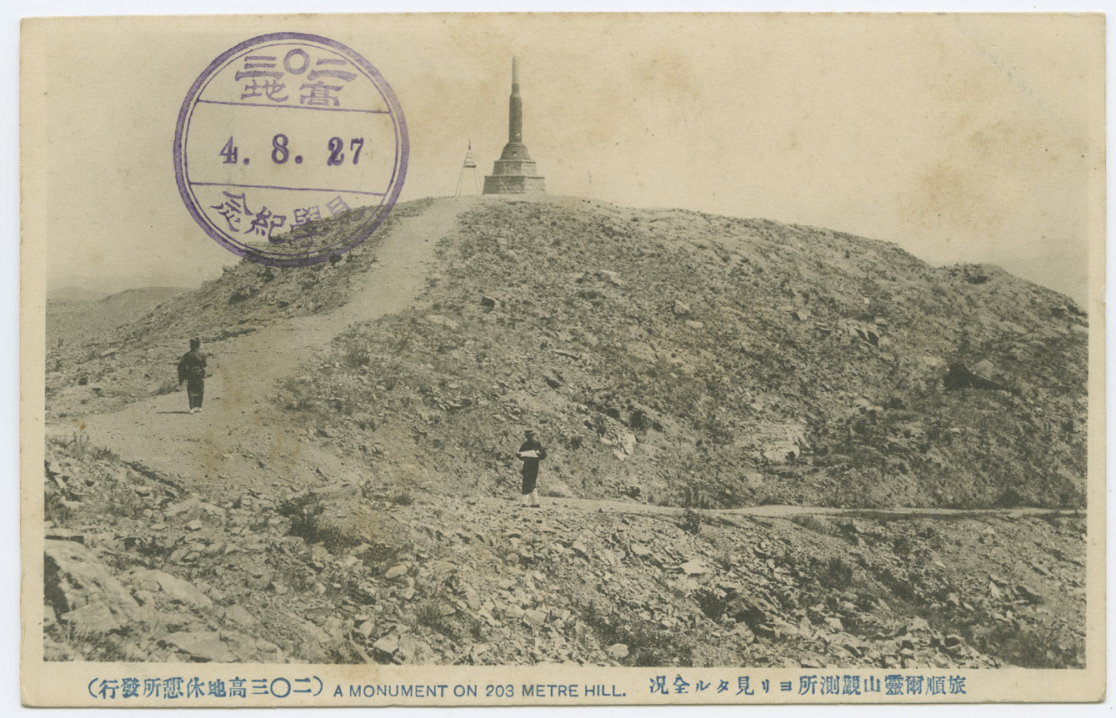

FIGURE 3. Travelers consult a map as they climb 203-Meter Hill. Postcard, c. 1915. The stamp reads, "203-Meter Hill, sightseeing souvenir" (kengaku kinen). Digital image courtesy of East Asia Image Collection, Lafayette College Libraries, Easton, PA. Image ip1201.

informal colonial rule in Manchuria fostered an emphasis on the national land in this context, it also exposed the underlying territorial anxiety of Japan's imperial nationalism. Indeed, as the remainder of the book suggests, the certainty with which the international community recognized Japan's formal colonization of Taiwan in 1895 and Korea in 1910 did little to lessen colonial boosters' sense of the need to constantly reanimate and reenact the nation's claims to these colonized lands. Nor did it dampen the amount of forgetting and re-remembering that such "observations" required.

Though Yosano Akiko would make no such claim herself when she traveled to Manchuria and Mongolia in the late 1920s, the Yosano of 1905 might have suggested that imperial travelers visiting the sites of Hideyoshi's campaigns in Korea consider what the stakes were of transposing a history of samurai-the class of military-aristocrats who governed the archipelago's feudal domains prior to the establishment of the centralized Meiji state-into a history of the kokumin. ${ }^{64}$ Official Japanese imperial nationalism argued that for centuries the Japanese state and its people had been trying, unsuccessfully, to reunite Korea with the Japanese imperial house and thus liberate Korea from its oppressive tributary relationship with China. Textbooks cast Hideyoshi's sixteenth-century campaigns as one moment in a history that stretched back sixteen hundred years to the invasion of 
the peninsula by Empress Jingū and the establishment of Mimana, a (mythical) small fief in the southern peninsula, and all the way forward to the colonization, or "annexation" (heigō), of Korea by Japan in 1910. ${ }^{65}$ Such a narrative organized the past in terms of the present. It cast the kind of tributary relations that structured foreign relations in East Asia prior to the advent of the Westphalian system as a necessary prehistory to the emergence of the nation-state, the harbinger of civilization and modern international relations, and thus trapped Korea behind Japan's supposedly more advanced temporal location. ${ }^{66}$ In reenacting this history, however, the transposition of a samurai invasion into national history also encouraged imperial travelers to understand the past of the archipelago not as a fundamentally different social order but rather as one in which Japanese-ness-in the sense of a national community - was always latent within the islands' people. Reenactment thus fostered in travelers the sense of themselves as products of and participants in the history of the nation rather than-as some who opposed the Meiji state in previous decades had argued-as products of a far more recent ideological campaign to reshape social life on the archipelago into the categories of an international order premised on competition and cooperation between nation-states.

Even within the category of "nation" and "national experience," imperial travelers' observations were fictionalized re-enactments of a national history rather than representations of shared experiences. In the European context, the "myth of the war experience" refashioned the memory of World War I into a "sacred experience, which provided the nation with a new depth of religious feeling and put at its disposal ever-present saints and martyrs, places of worship and a heritage to emulate." ${ }^{\prime 6}$ In the case of 203 -Meter Hill, what the student travelers needed to forget in order to remember was the fact that, as elite students, they were not and largely would not have been asked to fight. Conscription, as Kikuchi Kunisaku has written, was a "poor man's lottery." ${ }^{68}$ As the next generation of leaders, the government offered elite students special terms of military service, which Kikuchi calls "government-authorized draft evasion," that included six-week service for normal school students and pay-your-own-way volunteer one-year service for other elite school graduates with access to significant financial resources (in contrast to the three-year terms of other conscripts). ${ }^{69}$ But in writing about their visit to Port Arthur, these students-even those on the 1906 Tokyo Higher Normal School trip, for whom the war was a recent memory-conveniently elided the uneven demands the state made of its subjects during the war. Instead, they argued that their firsthand encounter with the battlefield gave them the authority to observe the meaning and history of the landscape in a way that those who had only read it about it could not.

The students' reenactments of the battle of 203 -Meter Hill as an intentional and meaningful sacrifice contradicted an ever-growing body of literature in the metropole about the futility of war. Much of the objection to war among the 
intelligentsia had been animated by the writings of Leo Tolstoy, who emerged during the war as a "symbol of antihierarchical cooperatist anarchist internationalism and moral resistance to the war and Japanese imperial expansion," as Sho Konishi puts it. ${ }^{\circ 0}$ Critics writing for the Heimin shinbun (People's newspaper) amplified his reframing of the war as a conflict not between Russian and Japanese soldiers, but between oppressed peoples and their oppressing states..$^{71}$ Following the war, critiques of the management of the war and, in particular, the wanton disregard for the lives of the conscripted, began to appear. One reason for the high number of casualties was not the violence of modern warfare but the inadequacy of supply chains, which left Japanese soldiers dead from beriberi (a vitamin B deficiency that would again be a problem in the Asia-Pacific War) and infection. Tayama Katai, a realist novelist known for his works Futon (Futon) and Inaka kyōshi (The country teacher), highlighted the meaninglessness of such deaths-and, by extension, the gap between nationalist fervor and individual experience-in his short story "Ippei sotsu" (One soldier). ${ }^{72}$ The story recounted the fictional tale of an injured soldier, who tried for days to get back to his battalion at the battlefront, only to die of beriberi before he could get there. That Tayama had been a journalist embedded with the army during the war lent the tale the air of realism. One former junior officer confronted the notion that the soldiers' deaths were purposeful sacrifices for the nation more bluntly: "Death in war is not about dying because one wants to die. One gets killed without really knowing what's going on. What's more, there is no guarantee of being killed. I personally don't believe that one can die that easily." 73 Yet imperial travelers readily clung to the "myth of the patriotic soldier," reenacting their courageous fights and honorable deaths on hills left purposefully devoid of such complicating factors. ${ }^{74}$

\section{THE COLONIAL ORIGINS OF IMPERIAL TRAVEL}

What I have sought to establish is a case for treating imperial tourism and its observational methodology as a particular kind of fiction, one that sought not only to place the Japanese nation on colonized lands but also to construct a vision of the Japanese nation as a coherent social body that could possess-with homogenous affect-a particular land. What I will suggest in closing is that the particularities of imperial tourism's fiction point to a genealogy that traces the practice's origins not to Europe's Grand Tour or to Tokugawa-era hot springs travel but rather to the practice of bringing elite colonized subjects on tours of the metropole. This genealogy reverses the standard narrative of tourism in which imperial railways expand outward, metropolitan subjects follow to gawk at the backwardness of colonized subjects, and then, many years later, colonized subjects who have adopted the bourgeois mentality and practices of the empire follow the same path back to the metropole to subvert the "tourist gaze." Instead, it suggests that both 
practices were part of the larger effort to produce and reproduce a hegemonic social imaginary in which identity was territorial and difference spatial. While this discourse existed in conversation with other tropes of colonial difference that circulated around race, ethnicity, and culture, it also existed as its own separate concern-one that could not be wholly addressed by recourse to racialized concepts of difference in the context of the burgeoning territorial nation-state system. The spatial politics of this social imaginary elided what Doreen Massey calls "geographies of solidarity" and what Nakanishi simply called "eyes" in favor of a territorial-national lens.

Subsequent chapters bear out this story for our largely metropolitan body of imperial travelers and the colonial boosters who sought to transform the new territories of the state into (new) national land. But it is worth pausing here to note that in the context of the Japanese Empire, the idea of using tourism to produce affective ties to particular territories - in this case, desire-began in 1897, in Taiwan. Indeed, the word for "tourism," kankō, was first applied not to imperial elites but rather to a group of thirteen indigenous leaders from Taiwan who were brought to Tokyo and other areas within Japan in 1897. As Jordan Sand points out, the characters that the government used to represent tourism "suggested both a civilizing function and the idea of duty to a sovereign." 75 The 1897 trip was followed in 1911 by a second trip (and then seven more before 1929). ${ }^{76}$ Over time, these "tours of the inner territory" (naichi kankō) were expanded to include other groups of colonized elites, including Koreans and Micronesians.

These tours of the metropole brought influential colonized subjects to Tokyo and other sites in the hope that a firsthand encounter with inner Japan would "shock and awe" these groups into submission. ${ }^{77}$ The Government General of Taiwan's early tours for Taiwan's indigenous peoples heavily emphasized the military might of Japan, but also the abundance, knowledge, and peacefulness of Japanese society. ${ }^{78}$ The itineraries suggested, not particularly subtly, that if indigenous peoples would put down their arms, they too would gain the benefits of Japanese modernity. In 1912, one group visited military garrisons in almost each town they stopped at, as well as a cannon factory, a bullet factory, and an armory in Tokyo. ${ }^{79}$ But they were also taken to sites emphasizing the lineage of the emperor, the beneficence of the imperial government, and the knowledge of the world and its flora and fauna that Japanese society possessed: the Meiji Memorial Colonization Exhibition in Tokyo, Asakusa Park, the zoos in Kyōto and Ueno, the aquarium at Sakai near Osaka; the Momoyama tombs near Kyōto; and the gardens at Kyōto's Myōshinji Temple. ${ }^{80}$

The Government General of Korea instituted a similar practice of tours of the metropole for Korean elites in 1909, just before the colonization of the peninsula. In the first decade of Japanese colonial rule, the Government General of Korea, the Japanese-owned Oriental Development Company, and the major pro-Japanese 
newspapers sent over a dozen "inner territory observation tours" (naichi shisatsu dan) to Japan. ${ }^{81}$ In line with the Government General of Korea's formulation of its mission in Korea, the Korean tours emphasized governance, industrialization, and agricultural science over the displays of military power that formed the core of itineraries for indigenous travelers. The Government General of Korea sought more than submission to Japanese rule. They aimed for a complete reformation (kairyō) of Korean society. For this reason, the Oriental Development Company also took Korean travelers to sites that exemplified local government and the cooperative nature of Japanese capitalism at the village level. They visited village governments, trade associations, and cooperative societies far off the beaten path, such as the Kako-gun Ishimori Village Buying, Selling, and Manufacturing Cooperative Credit Society in Hyōgo Prefecture. ${ }^{82}$

From this perspective, the observational travel of the new territories that began in 1906 offered a sort of photographic negative of the many Japans of colonial tourism. If for colonized travelers, tours of the metropole presented a vision of the inner territory that suited the needs of each particular colonial formation, for imperial travelers, one of the goals of observational travel was to subsume the many different subject positions that existed within the Japanese Empire to a singular relationship of a national subject to a national land. These were the dual "eyes" of imperial travelers - on the one hand, the eyes of an elite tasked with educating the masses and, on the other, the eyes of a generic national subject whose experiences of the colonies could believably stand in for the experience of any of his or her compatriots. Indeed, Kanō, the principal of Tokyo Higher Normal School, embedded this idea of a social imaginary in his description of the work of enlightenment that student travelers and future teachers would do. He did not use the word associated with the eighteenth-century European Enlightenment (kaika) but rather the word for enlightening as a pedagogical act (keihatsu), a word that was closer to illuminating or edifying, the enlightenment children experience through education. ${ }^{83}$ Kanō argued that travel to Manchuria was "witnessing" or firsthand observation, but really it was meant to be a kind of training in a particular orientation to colonized territory as national land that leaders in education and the army hoped would be transmitted to the population at large. For this reason, the Tokyo Asahi Newspaper argued that teachers should also be sent. Sending elementary school teachers would give these influential figures the "knowledge necessary to grant present and future children the qualifications for being new subjects (shinkokumin) of a newly powerful country (shinkōkoku)." ${ }^{84}$ An arrangement of partial central government support was soon announced for teachers. The travelers themselves would cover the remaining costs, though in many cases, prefectural governments provided considerable support. ${ }^{85}$

It was precisely this act of transposition and dissemination that the framers of imperial travel hoped to achieve. The elite status of early travelers presented 
a rather different group than what we might expect from a history of tourism, which has long been considered to be a form of mass leisure, in contrast to the more individualized and elite travel cultures that came before. ${ }^{86}$ But while domestic travel had been a popular leisure activity in Japan-and would continue to be so throughout the twentieth century-travel to the colonies was prohibitively expensive. The initial student tour of Manchuria in 1906 cost thirty yen-roughly what one higher normal school student could expect to spend in a year. This was despite the fact that the Japanese Imperial Army provided complimentary transportation to Dairen on army ships. ${ }^{87}$ Even seventeen years later, in 1923, the Japan Tourist Bureau estimated the cost for a two-week trip through Korea and Manchuria at 140 yen for a third-class ticket and a whopping 287 yen for first class. ${ }^{88}$ Given that tuition for one year at the prestigious Keiō University ran 120 yen and one year at Waseda University cost 110 yen, even a third-class trip would have been a considerable luxury. ${ }^{89}$ Travel to Taiwan was even further out of reach. The Osaka Mercantile Shipping Company published new sixteen-day itineraries for travel to Taiwan in 1924, which listed the price of first-class travel at 374 yen, second class at 261 yen, and third class, an option that had not been available the previous year, at 170 yen. ${ }^{90}$

The central government, colonial administrations, and colonial enterprises endeavored to lower the cost to individuals. Student discounts provided by the South Manchuria Railway Company and the Osaka Mercantile Shipping Company, whose steamers replaced complimentary army travel, brought the student itinerary down to eighty yen. Itō Takeo, who later published a memoir of his time as a member of the South Manchuria Railway's Research Bureau, described a seventy-five-yen trip through Korea, Manchuria, and China he took in 1917 as "cheap," but this determination reflected either his position as a student at the prestigious Tokyo Number One Higher School or his understanding that the price was cheap relative to the cost of such an endeavor outside the context of student group travel. ${ }^{91}$ By the 1920s, when government support waned, colonial enterprises, such as Mitsui Heavy Industries and Bank of Chōsen, also sponsored scholarships for higher commercial school students. ${ }^{92}$ While the expense of each trip slowly lowered as transportation companies developed further discounts for travelers, a tour of the empire never became cheap enough to be affordable to the masses. In 1930 the majority of Japanese households (some 65 percent) reported an income of between 200 and 800 yen a year, with some 17 percent earning less than 200 yen per year. While a wide range, these figures suggest that sending a single traveler on an 80- to 110-yen journey would, at best, have cost the average family more than one month's income. It was more likely, however, was that such a trip was far beyond the financial capacity of most. ${ }^{93}$

But the elite status of imperial travelers allowed them to amplify their observations of the new territories upon their return, and for this reason, they were the 
target audience in imperial tourism's early years. In contrast to Japanese settlers, who crowded belowdecks to travel to Korea and Manchuria and often had bring enough food to sustain themselves and their families for the trip, early imperial travelers went forth with as much pomp and circumstance as government ministries and local newspapers could muster. ${ }^{94}$ When Tochigi Prefecture's Shimotsuke Newspaper sponsored a group of industrialists on an observational trip to Manchuria and Korea in 1909, for example, the Japanese Bureau of Railways spared no expense in taking advantage of the publicity that the newspaper sponsorship offered. For their trip from Tokyo's Shinbashi Station to Shimonoseki, where they would board the ferry to Pusan, the Bureau of Railways attached a special second-class car that seated seventy-one people, so the group could stay together. On the outside of the car, the bureau painted "Tochigi Prefecture Industrialists' Manchuria-Korea Tourist Group Sponsored by Shimotsuke Newspaper" (Shimotsuke shinbun shusai Tochigi ken jitsugyōka Man-Kan kankōdan) on both sides. ${ }^{95}$ For the journey between Hōten (C. Fengtian; English [E.] Mukden) and Chōshun, the South Manchuria Railway Company provided a special first-class car, which the members of the group found so luxurious they all instantly declared their intention of becoming shareholders in the joint-stock company. ${ }^{96}$ Upon their arrival, they were guided and feted by local chambers of commerce and prefectural associations, such as the Pusan Tochigi Prefectural Association, whose members met the arrival of their ferry waving large banners that read, "Welcome Shimotsuke Tourist Group." ${ }^{97}$

For students, their elite social position likewise granted them the ability to disseminate their observations through the privileged venues they had access to. There was a vibrant market for their new knowledge. Student travelers spoke to their peers as well as to alumni and others interested in hearing what these travelers had learned about the empire. The Tokyo Number One Higher School Travel Club organized, for example, exhibitions that displayed photographs and memories of the trip, as well as a lecture series where students could present their findings. ${ }^{98}$ Other schools also offered public presentations and published reports in alumni magazines. By far the most common evidence we have of the self-consciousness of these students about the social value of their travels, however, are the extensive travelogues that many groups published upon their return. Often running hundreds of pages, these reports detailed the journey from beginning to end so that they might serve as a blueprint for future travelers. They also included essays on the current state of various industries and institutions, such as elementary education and banking, "not only so that the students' observations (kenbun) might be disseminated, but also because the results of their investigations and research deserve attention."99

Like the industrialists, who one impoverished Japanese settler complained spent their time "running around in all directions looking for business 
opportunities," the students saw imperial travel as a chance for personal gain. ${ }^{100}$ In this way, imperial tourism united the nationalist "to rise in the world" (risshin shusse) ideal of Tokutomi Sohō with the younger generation's more individualistic version of the slogan of which he was so critical. As members of the growing "new middle class," elite student travelers treated their firsthand knowledge of colonized lands as, in the words of one Hiroshima Higher Normal School traveler, "our capital for the future."101 Like the trans-Atlantic "sociological grand tours" of American progressives in the early twentieth century, for rising members of Japan's new middle class, firsthand experience from the front lines of empire was particularly coveted as a mark of distinction and knowledge. ${ }^{102}$ Some students would use their firsthand knowledge directly as teachers of the next generation. Others would serve as bureaucrats in the metropolitan and colonial administrations, faculty in Japan's universities, and white-collar labor in a growing industrial and financial sector that now extended into Taiwan, Manchuria, and Korea. Indeed, while records of the individuals who traveled to the continent during this period are scarce, the roster of the 1912 Tokyo Number One Higher School trip to Manchuria and Korea reads like a who's who of the next thirty years of Japanese intellectual, cultural, and political history. Yasui Seiichirō went on to head the Tokyo Social Welfare Department before serving as private secretary to Governor General of Korea Ugaki Kazushige and then, in 1940, governor of the prefecture of Niigata. Wada Sei became a professor of Oriental history, authored numerous works on the history of Manchuria, Mongolia, China, and East Asia, and managed the Oriental Library (Tōyō bunko), prewar Japan's most prestigious library and research center for the study of Asia. Capping them all was Yanaihara Tadao, who took over the chair of colonial studies (Shokuminchi seisaku gaku) at Tokyo Imperial University from his mentor, Nitobe Inazō, and went on to become one of the most vociferous and well-known critics of Japanese colonial policy in the 1920 and 1930 s. $^{103}$

Student travelers relished the position of responsibility that Kanō had placed upon his students, casting themselves as privileged guardians of the nation's future. Sightseeing in the Russian-controlled city of Harbin (C. Haerbin) in northern Manchuria on July 30, 1912, students from Tokyo Number One Higher School received a call from the consulate with the news that the Meiji emperor had died. "I thought of the future and cried," one diarist wrote. "As the generation of the future, our group of twenty-four had no choice but to cry." ${ }^{104}$ Another student, this time from the 1915 Hiroshima Higher Normal School trip, felt his future responsibility settle over him as the group gathered on the pier in Pusan: "As we boarded the Shiragi-maru in preparation for leaving the continent, the position of our empire came to mind. Our responsibility as educators pierced our chests anew." ${ }^{105}$ Local officials reinforced the message. Another student recalled a particularly memorable meeting in Port Arthur with Shirani Takeshi, the civil governor of 
the Kwantung Leased Territory. "How is it?" he asked, after the students visited the memorial to Japan's war dead atop 203-Meter Hill. "Have you come to understand the value of Japan?"106

Both colonized and metropolitan travelers found ways to critique the representations of spatial difference and territorialized identity that they encountered. Colonial and metropolitan police censored the official reports of the trips of the colonized subjects, in some cases even revising the original comments into more positive statements. ${ }^{107}$ But critical comments trickled through. Indigenous travelers mocked the Japanese government's insistence on its own peacefulness, wondering why such a peaceful country would spend such time and resources stockpiling weapons. Others found the stark core-periphery logic of the civilized metropole and savage frontier unconvincing, commenting that Japanese people (naichijin) "live like ants." ${ }^{108}$ Moreover, submission to Japanese rule was no given. Mona Rudao, the alleged leader of the 1930 Musha uprising in Taiwan, was a participant in one tour. Likewise, some Korean students reported discovering the extent of colonial discrimination through tours of the metropole, when they saw the difference between the science laboratory facilities at metropolitan schools and those at their own colonial schools. ${ }^{109}$

In the case of Japanese travelers, overt critiques were likewise rare. But one in particular was prescient. Reversing observational travel's practice of collapsing the experience of one into the shared affect of many, one diarist for Hiroshima Higher Normal School commented on the potential for individuals in Dairen to create problems for the many. "Once you've familiarized yourself with this place," he wrote, "you can't help but agree that, like one wave becoming ten thousand waves, an action by the people on the South Manchuria Railway Company route will come to the metropole and become a problem for the whole country."110

\section{CONCLUSION}

In the years after the Russo-Japanese War, the Japanese government, colonial governments, and colonial institutions set about creating a nation that had affective ties to Manchuria and Korea. Imperial travelers were, for the most part, willing participants in this process, performing their kokumin-ness through their emotional involvement with the national land. Indeed, despite the wide range of critiques that circulated during and after the war, the basic premise of a territorialized national identity would largely go unchallenged by imperial travelers in their writings on empire. Instead, the debate turned to whether and how these colonized lands ought to be placed within Japan. But critiques of imperial travelers' nationalist eyes, such as Nakanishi's, would continue to play a significant role in shaping the spatial politics of empire-if only, as we shall see in later chapters, to outline the boundary beyond which the issue could not be debated. 
The point to be gleaned from the emergence of observational travel to the new territories at this time is that the state's concern with producing subjects with affective ties to colonized land was as much a project of naturalizing the territorial nation-state as it was legitimating the scope of Japan's empire. As we shall see in later chapters, the images of Korea, Manchuria, and, later, Taiwan, as places within the Japanese nation and the image of Japan as a nation in place on these lands were shaped by crises more concrete than a conceptual kerfuffle over territoriality and community in a system of territorial nation-states. At the same time, we should not ignore the centrality of the land to the ideological project of observational travel and imperial tourism. Imperial tourism was one component of a spatial politics that sought to construct a social imaginary of the nation that was inseparable from its spatial imaginary. In the broad sense, the spatial politics that emerged in the early twentieth century drew on symbolic-cultural elements of nationalism, such as commemorative practices, geography education, and landscape ideology, as well as its political and technological practices, such as establishing international boundaries and cadastral surveys, to make the land under Japanese administration manageable as territory of the state and meaningful as the space of the nation. In the more narrow sense, the Ministry of Education and other actors conceived of observational travel's contribution to that spatial politics as mediating and, in some sense, fostering ties between state and nation through the observation of the land itself.

This suggests that the story of the social imaginary of modern Japan-what Marilyn Ivy calls the "national-cultural imaginary" of Japan-must necessarily be "re-routed" through Manchuria, Korea, and Taiwan. ${ }^{111}$ In the first place, the ideological force of observational travel begins to illuminate how the boundaries between practices of "nationalization" and "imperialization" were intertwined, with colonial travelers brought to the metropole to develop a sense of themselves as part of the space of the Japanese Empire and metropolitan travelers sent to the colonies to develop a sense of themselves as a part of a nation that included colonized lands. Of course, the stakes of "becoming Japanese" differed starkly for each group. But for neither group was the spatial imaginary of the nation a natural phenomenon. Rather, it had to be taught and, the colonial boosters hoped, internalized in order for imperial nationalism to be reproduced. Indeed, it is for that reason that this book begins with the intertwined relationship of national people (kokumin) and national land (kokudo) that travel produced, rather than with the expansion and integration of the imperial transportation network, a more standard starting point for histories of tourism.

In the second place, specific understandings of Japan and its place in the world emerged from imperial travelers' and colonial boosters' attempts to place these colonized lands within the space of the nation but without, as Nakanishi argued, its tangled web of social and historical relations. In this chapter, we explored the 
production of a shared history through the reenactment of a national past in Korea and Manchuria. These wars of conquest remain central elements of popular and official national history. They also remain powerful tourist sites, with travelers returning to Port Arthur and to the remains of Hideyoshis invasion of the Korean peninsula even today. Such "nostalgia tourism," as Mariko Tamanoi has argued, not only "represents the nation's yearning for the landscapes, lifestyles, and spectacles of the lost empire" but also sustains the basic erasures of imperial observational travel by "assisting the Japanese people to forget the power of their own state, which once dominated ordinary Chinese people in a place where they now entertain themselves." ${ }^{112}$ Indeed, as Scott Laderman has argued in the case of U.S. tourism to Vietnam, nostalgia tourism reproduces nationalist history's "taking" of places by reducing them to waypoints in a narrative of national rise and decline while at the same time erasing other perspectives on the meaning of these sites and of the power relations that shape what constitutes meaningful history for different audiences. ${ }^{113}$ Nostalgia tourism has not erased the history of empire, in other words, but rather has sustained the concept of a national land that exists as a place distinct from the other past-places that share the same land. ${ }^{114}$

A history of imperial tourism that stretches not from 1905 to 1945 but from 1897 to the present raises questions for our idealized imaginary of the nation-state as a territorialized community. What the prevalence of so many different tools, discursive and material, for territorializing a Japanese nation on colonized land suggests is that the territorialized nation is largely a myth. This is not to say that nations did not or do not imagine themselves to be rooted in a particular territory. It was, of course, precisely this pursuit of territorialization that motivated imperial tourism and other modes of addressing the gap between state and nation. But to define nations as themselves territorialized implies an achievement; instead, we ought to be analyzing a process. Shifting our terminology from territorialized to territorializing calls attention to the continuous work required to sustain the spatial imaginary of nationalism and to how this work is never complete but rather must persist in order to respond to the changing conditions of empire and nation. 